\title{
The Intention of Investing Sharia Stocks on Millennials: The Role of Sharia Financial Literacy
}

\author{
Multazam Mansyur Addury' ${ }^{1 *}$, Anton Priyo Nugroho ${ }^{2}$, \\ Salehuddin Khalid ${ }^{3}$ \\ 1, 3Sekolah Tinggi Ekonomi Islam (STEI) Yogyakarta, Yogyakarta, Indonesia \\ 2Faculty of Islamic Studies, Universitas Islam Indonesia, Yogyakarta, \\ Indonesia \\ *multazam.mansyur@gmail.com
}

\section{Article History}

\begin{tabular}{lll}
\hline Received & $:$ & $2020-12-01$ \\
\hline Revised & $:$ & $2020-12-02$ \\
\hline Accepted & $:$ & $2020-12-04$ \\
\hline
\end{tabular}

\section{Abstract}

Introduction to The Problem: Millennials are a generation that has a very rapid growth. More than 30 percent of Indonesia's population is millennials, but many of the Millennials have not been intentioned in investing in sharia stocks.

Purpose/Objective Study: The purpose of this research is to examine the impact of sharia financial literacy on Millennials on the intention of investing in sharia stocks, or it has other factors.

Design/Methodology/Approach: This research used Sharia financial literacy and the Theory of Planned Behavior. This research used five variables namely Sharia financial literacy, attitudes, subjective norms, behavioral controls, and intentions. This study used purposive sampling method, from muslim millennials in Yogyakarta. Total respondents to this study are 112 with 20-40 years old or a millennials generation and already have income. Multiple linear regression analysis techniques used as primary analytical techniques.

Findings: The results proved that Sharia financial literacy and subjective norms did not affect the intention of investing in sharia stocks. Other variables, such as behavioral attitudes and controls, proved to have a significant influence on the intention of investing in sharia stocks.

Paper Type: Research Article

Keywords: Millennials; Sharia Stocks; Sharia Financial Literacy; Theory of Planned Behavior.

Ihtifaz: Journal of Islamic Economics, Finance, and Banking
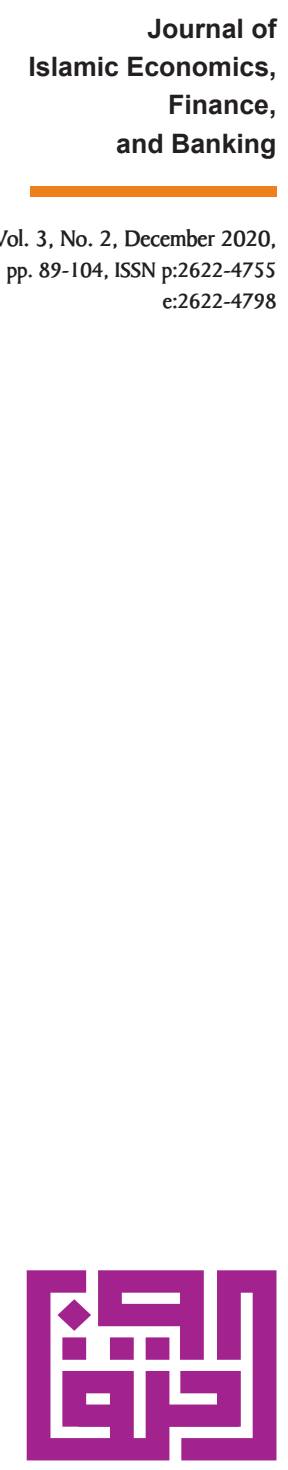

IHTIFAZ

UNIVERSITAS AHMAD DAHLAN

Kampus 4

Universitas Ahmad Dahlan Il. Ringroad Selatan, Tamanan Banguntapan, Bantul Yogyakarta 55191 e-mail : ihtifaz@uad.ac.id 


\section{INTRODUCTION}

Economic growth is good enough in Indonesia, making the needs of IHTIFAZ - JIEFB people will also increase. This condition indirectly makes the community think about how to get additional incomes. Stock investing in capital markets is an investment that can be done today to gain an additional income without disrupting the main work.

Based on OJK data in March 2019, the number of investors in the capital market reached 1.7 million investors. It shows the high demand for people to invest. However, from the number of investors, about $85 \%$ to $90 \%$ can be said as failed investments. It happens because the investors do not have the right level of understanding regarding the investment world. Also, investors are often stuck in technical data regardless of the fundamental company, and this is what makes them a trading trader only.

In stock investing, an investor faced with two factors of consideration, namely the rate of return and the risk that can likely occur. The consideration factors require a good understanding of literacy. A national survey conducted by the Financial Services Authority (OJK) in 2017, found that sharia financial literacy is still much lower than the level of conventional financial literacy. Sharia financial literacy is only $8 \%$ compared to the conventional financial literacy that reaches 30\% as for Sharia financial inclusion only reached about $11 \%$ compared with conventional financial inclusion, which reaches a $68 \%$ rate. The lousy level of literacy makes Indonesia get 10th rank in the market share in world Sharia finance. Financial literacy aims to educate the procedures of excellent and intelligent financial management. Four aspects are part of financial literacy, i.e., savings, loans, insurance, and investment. The understanding of these four aspects can minimize the risk of loss.

Many studies have proved that financial literacy influences on the intentions of investing as has been done by Faidah (2019), Salsabila \& Nurdin (2019), and Darmawan et al., (2019). The study attempted to use The Theory of Planned Behavior (TPB) propounded by Ajzen (1991). The Theory of Planned Behavior is a theory that considers the intention of one's behavior to formed by three factors i.e., attitude, subjective norm, and behavioral control (perceived behavioral control). As the time progresses, this theory has been modified several times in research by adding additional variables that make up one's intention to behave, such as that of Nugroho et al., (2017), Paul et al. (2016), Denan et al., (2015), and Nugroho et al., (2019). The models of the study proved that the theory of TPB could be extended by adding new variables to strengthen the prediction power of TPB.

The development of Indonesia population has reached approximately 260 million. At the population level, the age group of $20-40$ years has a sufficiently high amount of about 88 million people. The age group can be said to be a millennial group. The high population of millennials 
in Indonesia is about 30 percent encouraging writers to review the intention of millennials to invest in Sharia capital markets. This Model of research uses Sharia financial literacy variables combined with TPB against intention to invest.

\section{Intention to Behave}

Fishbein \& Ajzen explains that intention is an estimate of how likely it is to take action by being influenced by certain factors (Fishbein \& Ajzen, 1977). Intention to behave can occur under control of consciousness and willpower. It means that individuals can take specific actions on their basis. The explanation contains the meaning that the firm intention of an individual, then the possibility to conduct actual behavior, is also increasingly more definite. In previous research, it can be proved by various experiments that behavioral intention can become predicting future behavior. The possibility of predicting behavior from the intent allows the emergence of various studies on intent-based behavior as opposed to researching actual behaviors.

\section{Sharia Financial Literacy}

According to the OJK, literacy is a level of understanding of the community in relation to financial aspects such as products, services, and financial principles. While Islamic financial literacy is the level of knowledge and ability of the community to make decisions related to sharia finance institutions (HC \& Gusaptono, 2020). Lusardi and Mitchell said that financial literacy is a level of understanding of finance and ability to apply it (Lusardi, 2019). Huston then explained that literacy is a measurement process of how well an individual understands and uses information about personal finances (Huston, 2010). It can be concluded that financial literacy is knowledge of the procedure of managing financial assets properly and correctly in order to avoid financial problems. Islamic financial literacy is a knowledge of the products of sharia financial institutions, sharia investments, RIBA, zakat, Waqf and using one of these products. In financial literacy there are important aspects to be known among such as basic understanding of personal finances, savings, debts, insurance, and investments. These four aspects are fundamental to financial literacy (Chen, 1998).

Financial literacy has various classifications based on levels from lowest to high. According to the OJK, the level of financial literacy is divided into four levels, namely: Well literate is to know and believe in financial institution products and have the skills to use financial products and services. Sufficient literate is the level of individuals who have the understanding and skills to utilize financial institutions ' products and services. Less literate is the level of individuals who only know financial institutions ' products and services. Not literate is the level of individuals who do not have any knowledge and skills to use the products and services of sharia financial institutions. The most dominant level occupied 
by sufficient literate then well literate next Less literate as well as Not literate, then the government launches a program on literacy education

to encourage Indonesia to have good financial literacy.

Several factors have an impact on individual literacy, namely: age, knowledge of personal finances and ability in mathematics, financial behavior of people, income gained every month. According to Mandell, demographics can be a factor affecting the level of financial literacy (Mandell, 2008). Usually, the level of literacy among teenagers is still lower compared to adults because of the level of education as well as the background of the family economy. Thus, based on the literacy of adults, income, having adequate education will have a higher level of literacy compared to those who are teenagers and not income earners. Sharia finance is a financial system used based on Islamic principles. The principle used by this system is undoubtedly according to the guidance of the Qur'an and hadith. The prohibition in sharia financial systems such as transactions must not contain elements of gambling, monopoly, RIBA, fraud, obscurity, hoarding, etc. The matters covered in Sharia finance include banking, insurance, capital. The matters covered in Sharia finance include banking, insurance, capital market, Pawnshop, BMT, zakat, Waqf, etc. (Muhamad, 2016).

The level of financial literacy will form people in managing their finances, for example, in terms of investments. A person who has good literacy will invest in keeping the value of their assets unaffected by inflation. One of the investment instruments that can be used is sharia stocks. Sharia stocks are proof of ownership that individuals in a particular company.

Many studies have proven that there is a correlation between financial literacy and entrepreneurial intention. Adi et al., (2018) conduct research on the relationship between financial literacy on entrepreneurial intention. In his research proved that financial literacy has a positive relationship with entrepreneurial intention. Later on Salsabila \& Nurdin (2019) found that financial literacy has a positive influence on investment decisions. Faidah (2019) conducts research on the influence of financial literacy on investment intentions and found that financial literacy has a positive relationship to investment intention in students. As well as Shofwa (2017) has been conducting research on the influence of financial motivation and literacy on the intention of investing the capital market, the results of this study found that there was a positive influence of financial literacy on intention. Based on the results of the above description can be taken hypotheses:

H1: Sharia financial literacy has a positive influence on the intention in investing stocks

\section{Attitude Toward Behavior}

Attitudes in general can be said as a form of evaluation of individuals on objects, intentions, events, people around, and intention in doing 

the attitude is not a behavior but rather a disposition about a particular behavior, attitudes describe a person's relationship with objects that are not neutral but are positive and negative, like or dislikes and so on (Fishbein \& Ajzen, 1977). Because attitude is the initial characteristic of the behavior then before the emergence of intention, millennials will emerge their attitude towards investment first.

Some of the following studies have proved a positive relationship in attitudes towards intention. Using the theory planned behavior approach, research from Adi et al. (2018) proves that the attitude has a positive relationship to intention. While research from Andika \& Madjid (2012) found there was a positive relationship between attitudes towards entrepreneurial intentions. Research by Nugroho et al., (2019) found an attitude relationship with the intentions of Halal cosmetics. In addition Arwani (2015) also found a positive relationship between attitudes and intentions. Based on the description, the hypothesis is:

H2: Attitude has a positive influence on the intention in investing stocks

\section{Subjective Norm}

Ajzen explains that the subjective norm is a factor outside of the individual to display behaviors to social stimuli in order to approve certain behaviors (Ajzen, 2005). According to him, this subjective norm is a social impetus that causes certain individuals to behave. Therefore, individuals are likely to form the same behavior as certain norms adopted by their social environment. A person will do certain behaviors if they get encouragement from an individual that is deemed important by him. Therefore, the encouragement or influence of others is one of the determinants of individual behavior (Fishbein \& Ajzen, 1977). If friends or companions are deprived of associations saying good things about investing in stocks, then it will encourage a person to intend to behave in a particular way. Likewise if a person gets a negative response regarding the investment of shares in his social environment will cause the individual to carry out his intention to invest in shares.

Many studies have proved a positive relationship between subjective norms of intention. The research conducted by Arwani (2015) proves the subjective norm has a positive relationship to the student intention in Sharia banks. Andika \& Madjid (2012) also proved that there is a correlation between the subjective norm and the intention of selfemployed students. Some other studies have also found the same results as the research of Van Gelderen et al. (2008) and Nugroho et al. (2019). Based on the description, the research hypothesis is:

H3: Subjective norm has a positive influence on the intention in investing stocks. 


\section{Perceived Behavioral Control}

Perceived behavioral control is an individual feeling of ease or IHTIFAZ - JIEFB difficulty in displaying behaviors. As the predictor of the behavior, Perceived Behavioral Control (PBC), uses the assumption if the intention that behaves is constant, then the easier behavior will be likely to emerge compared to the more difficult behaviors. Essentially that ease becomes the thing that makes the individual to behave. Ajzen (2005) explains that one's behavior is not only self-controlled but requires control, such as resource availability and even certain skills. Ajzen therefore says behavioral control reflects the dimension of difficulty received or the difficulty of performing a particular behavior. If the individual considers stock investing to be easy and enjoyable then the individual will do so. Likewise, if the individual considers the investment of shares that complicate itself, the individual will not do so. Many studies have proved a positive relationship between control and intention in investing. Such research was done by Ruslim et al. (2017), Sulistianingtyas, Sulistianingtyas et al. (2018), and Saud (2016). Based on the description, the research hypothesis is:

H4: Perceived behavioral control has a positive influence on the intention in investing stocks.

Based on the results of the description, the following research model.

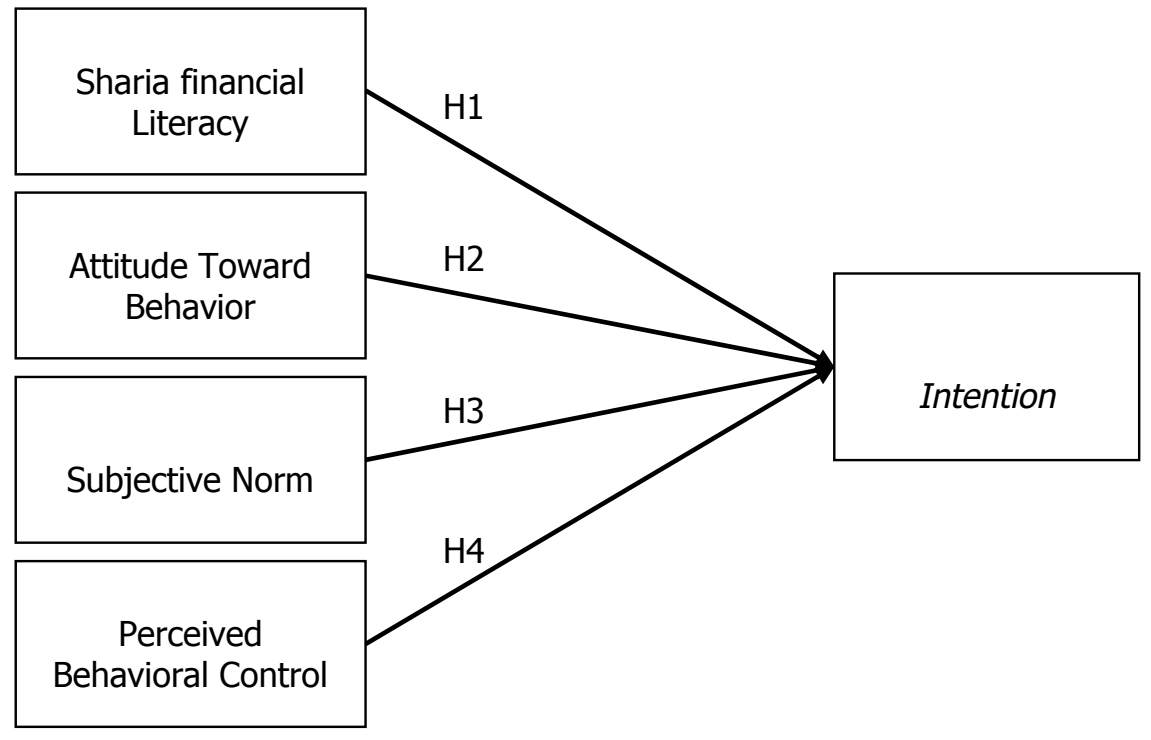

Figure 1. Research Model

\section{METHODOLOGY}

This research is causality research that is the type of research with relation characteristics. This study conducted with prophetic quantitative methodology. Sampling technique using purposive sampling method, 
from Muslim millennials in Yogyakarta. Total respondents to this study are 112 with $20-40$ years old or a millennials generation and already have income.

The measurement of Sharia financial literacy, attitudes, subjective norms, behavioral controls, and intentions used direct assessment methods, which implemented in using single or double items. The research used a self-administered questionnaire. In the questionnaire, the attitude variables have five question items; the subjective norm has three question items; the behavioral control has three question items and the intention of having four-item questions. Answers from respondents were measured using continuous rating scales, which points start from the worst to the best of the category (Nugroho, 2015). Sharia financial literacy is measured using the Guttman scale; this scale provides two answers: "Correct" and "wrong." The number of questions on Sharia financial literacy is ten items. The total number of questions asked to respondents amounted to 25 questions.

\section{RESULTS AND DISCUSSION}

\section{Descriptive Analysis}

From 112 respondents, they were dominated by males of approximately 67 percent and women about 33 percent. Respondents who are $20-25$ years old are 65.2 percent, $26-30$ years i.e., 20.4 percent, $31-35$ years 10.8 percent, and 35-40 years 3.6 percent. In terms of work, the respondents of civil servants 11.6 percent, employees of BUMN 8.9 percent, self-employed 31.3 percent, students 25 percent, and others 23.2 percent. In terms of revenue, the respondents were monthly income below 1.5 million, around 25 percent, $1.5-3$ million 34.8 percent, 3-5 million 24.1 percent, and over 5 million 16.1 percent. While in terms of education, the majority of respondents were scholars of 52.7 percent, SMA 25.9 percent, Diploma 6.2 percent, other 8 percent, and SMP 7.1 percent. From the investment products used, dominated by Sharia insurance 40.2 percent, sharia stocks 15.2 percent, Sharia capital market 22.3 percent, Sharia bonds 4.5 percent, and Sharia mutual fund is 17.9 percent. In terms of activities to invest Sharia stocks, the majority of respondents have never made investments are 55.4 percent, and who have done only about 44.6 percent. The following is a table of respondents' responses to research variables using the three box analysis.

Table 1. Respondents' Response to Sharia Financial Literacy

\begin{tabular}{|c|c|c|c|}
\hline No & Response & Amount & Percentage \\
\hline 1 & Good & 96 & $85,7 \%$ \\
\hline 2 & Enough & 15 & $13,4 \%$ \\
\hline 3 & Low & 1 & $0,9 \%$ \\
\hline \multicolumn{2}{|r|}{ Total } & 112 & $100 \%$ \\
\hline
\end{tabular}

Source: Primary Data (2019) 
Table 2. Respondents' Response to Attitude

IHTIFAZ - JIEFB

\begin{tabular}{clcc}
\hline No & Response & Amount & Percentage \\
\hline 1 & Agree & 84 & $74,8 \%$ \\
2 & Simply agree & 23 & $20,7 \%$ \\
3 & Disagree & 5 & $4,5 \%$ \\
\hline \multicolumn{2}{r}{ Total } & 112 & $100 \%$ \\
\hline
\end{tabular}

Source: Primary Data (2019)

Table 3. Respondents' Response to the Subjective Norms

\begin{tabular}{cccc}
\hline No & Response & Amount & Percentage \\
\hline 1 & Recommended & 73 & $65 \%$ \\
2 & Simply recommended & 33 & $29,6 \%$ \\
3 & Not recommended & 6 & $5,4 \%$ \\
\hline \multicolumn{2}{c}{ Total } & 112 & $100 \%$ \\
\hline
\end{tabular}

Source: Primary Data (2019)

Table 4. Respondents' Response to the Behavioral Control

\begin{tabular}{clcc}
\hline No & Response & Amount & Percentage \\
\hline 1 & Sure & 76 & $67,7 \%$ \\
2 & Pretty sure & 32 & $28,7 \%$ \\
3 & Not sure & 4 & $3,6 \%$ \\
\hline \multicolumn{2}{c}{ Total } & 112 & $100 \%$ \\
\hline
\end{tabular}

Source: Primary Data (2019)

Table 5. Respondents' Response to the Intention

\begin{tabular}{clcc}
\hline No & Response & Amount & Percentage \\
\hline 1 & Intend & 79 & $70,3 \%$ \\
2 & Simply intend & 28 & $25,2 \%$ \\
3 & No intention & 5 & $4,5 \%$ \\
\hline \multicolumn{2}{c}{ Total } & 112 & $100 \%$ \\
\hline
\end{tabular}

Source: Primary Data (2019)

\section{Validity and Reliability Test Results}

The results of validity and reliability tests can be seen in the table below. If the significance of the items above 0,3 then it can be said to be valid (Sujarweni, 2008). 
Table 6. The Results of the Shariah Financial Literacy Variable Validation Test

\begin{tabular}{ccccc}
\hline Item & $\mathbf{N}$ & $\mathbf{r}$ table & r count & Description \\
\hline 1 & 30 & 0,312 & 0,720 & Valid \\
2 & 30 & 0,312 & 0,474 & Valid \\
3 & 30 & 0,312 & 0,583 & Valid \\
4 & 30 & 0,312 & 0,642 & Valid \\
5 & 30 & 0,312 & 0,674 & Valid \\
6 & 30 & 0,312 & 0,583 & Valid \\
7 & 30 & 0,312 & 0,561 & Valid \\
8 & 30 & 0,312 & 0,638 & Valid \\
9 & 30 & 0,312 & 0,583 & Valid \\
10 & 30 & 0,312 & 0,572 & Valid \\
\hline
\end{tabular}

Islamic Economics,

Finance, and Banking

Vol. 3, No. 2, December 2020, pp. 89-104, ISSN p:2622-4755

Source: Primary Data (2019)

Table 7. The Results of the Attitude Variable Validation Test

\begin{tabular}{lllll}
\hline 11 & 30 & 0,312 & 0,879 & Valid \\
12 & 30 & 0,312 & 0,914 & Valid \\
13 & 30 & 0,312 & 0,918 & Valid \\
14 & 30 & 0,312 & 0,870 & Valid \\
15 & 30 & 0,312 & 0,878 & Valid \\
\hline
\end{tabular}

Source: Primary Data (2019)

Table 8. The Results of the Subjective Norm Variable Validation Test

\begin{tabular}{ccccc}
\hline Item & $\mathbf{N}$ & r table & r count & Description \\
\hline 16 & 30 & 0,312 & 0,917 & Valid \\
17 & 30 & 0,312 & 0,949 & Valid \\
18 & 30 & 0,312 & 0,947 & Valid \\
\hline
\end{tabular}

Source: Primary Data (2019)

Table 9. The Results of the Behavioral Control Variable Validation Test

\begin{tabular}{ccccc}
\hline Item & $\mathbf{N}$ & r table & r count & Description \\
\hline 19 & 30 & 0,312 & 0,860 & Valid \\
20 & 30 & 0,312 & 0,886 & Valid \\
21 & 30 & 0,312 & 0,920 & Valid \\
\hline
\end{tabular}

Source: Primary Data (2019) 
Table 10. The Results of the Intention Variable Validation Test

IHTIFAZ - JIEFB

\begin{tabular}{ccccc}
\hline Item & $\mathbf{N}$ & $\mathbf{r}$ table & r count & Description \\
\hline 22 & 30 & 0,312 & 0,907 & Valid \\
23 & 30 & 0,312 & 0,928 & Valid \\
24 & 30 & 0,312 & 0,875 & Valid \\
25 & 30 & 0,312 & 0,939 & Valid \\
\hline
\end{tabular}

Source: Primary Data (2019)

Based on these validity tests, all of the question items can be declared valid and can be used for research. Furthermore, the following reliability test results from the question item:

Table 11. Reliability Test Results

\begin{tabular}{llll}
\hline \multicolumn{1}{c}{ Variable } & $\begin{array}{c}\text { Cronbach } \\
\text { Alpha }\end{array}$ & Standard & Description \\
\hline Sharia financial Literacy & 0,770 & 0,60 & Reliable \\
Attitude & 0,931 & 0,60 & Reliable \\
Subjective norm & 0,931 & 0,60 & Reliable \\
Behavioral control & 0,875 & 0,60 & Reliable \\
Intention & 0,933 & 0,60 & Reliable \\
\hline
\end{tabular}

Source: Primary Data (2019)

The table above shows that the five variables are reliable and can be used for subsequent research.

\section{Classic Assumption Test}

The classical assumption test consisted of linearity test, normality test, heteroskedasticity test, and multicollinearity test. Here are the classic assumption test results.

Table 12 . Results of Linearity Test

\begin{tabular}{lll}
\hline \multicolumn{1}{c}{ Variable } & F Sig & Sig \\
\hline Sharia financial Literacy & 1,678 & 0,146 \\
Attitude & 1,765 & 0,025 \\
Subjective norm & 4,583 & 0,000 \\
Behavioral control & 1,364 & 0,000 \\
\hline
\end{tabular}

Source: Primary Data (2019) 
Table 13. Results of Normality Test

\begin{tabular}{lc}
\hline \multicolumn{1}{c}{ Variable } & Kolmogorov-Smirnov \\
\hline Sharia financial Literacy & 2,520 \\
Attitude & 1,082 \\
Subjective norm & 1,593 \\
Behavioral control & 1,482 \\
Intention & 1,340 \\
\hline
\end{tabular}

Source: Primary Data (2019)

Table 14. Results of Multicollinearity Test

\begin{tabular}{lcc}
\hline \multicolumn{1}{c}{ Variable } & Tolerance & VIF \\
\hline Sharia financial Literacy & 0,888 & 1,126 \\
Attitude & 0,211 & 4,735 \\
Subjective norm & 0,229 & 4,370 \\
Behavioral control & 0,186 & 5,381 \\
\hline
\end{tabular}

Source: Primary Data (2019)

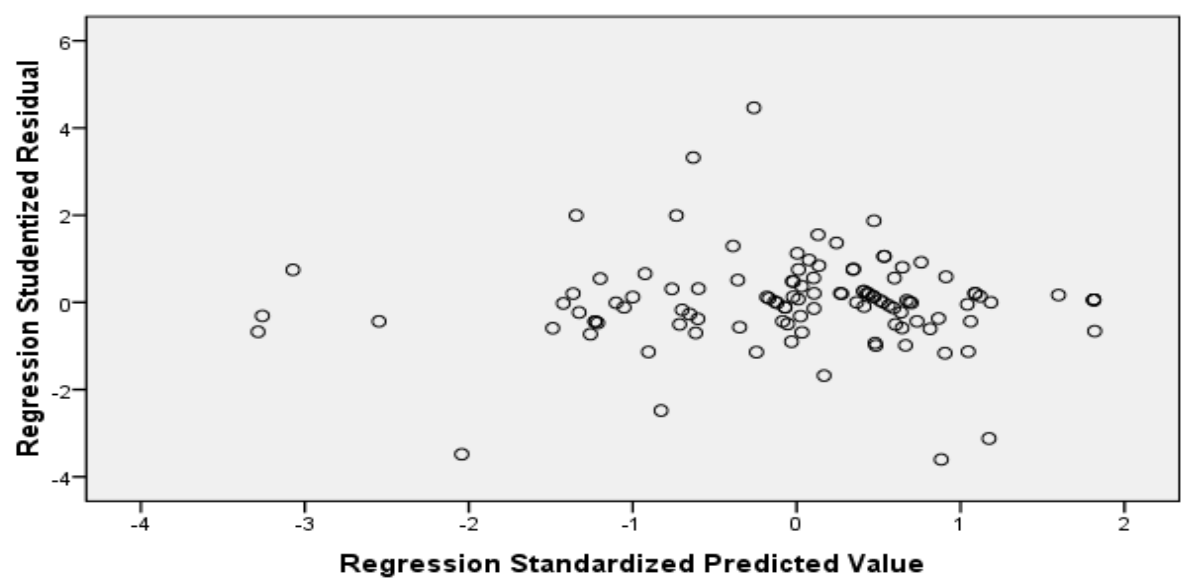

Source: Primary Data (2019)

Figure 2. Heteroskedasticity Test Results

\section{Multiple Linear Regression Analyses}

Multiple linear regression analyses are used to determine how independent variables are affected (sharia financial literacy, attitudes, subjective norms, behavioral control) over dependent variables (intentions). 


$$
Y=b 0+b 1 . X 1+b 2 . X 2+b 3 . X 3+b 4 . X 4
$$

IHTIFAZ - JIEFB

Description:

$\begin{array}{ll}\text { Y } & =\text { Intentions } \\ \text { b0 } & =\text { Constant } \\ \text { b1-b4 } & =\text { Coefficient } \\ \text { X1 } & =\text { Sharia financial literacy } \\ \text { X2 } & =\text { Attitudes } \\ \text { X3 } & =\text { Subjective norms } \\ \text { X4 } & =\text { Behavioral Control }\end{array}$

Multiple linear regression test results can be seen in the following table:

Table 15. Multiple Regression Test Results

\begin{tabular}{lrrrr}
\hline \multicolumn{1}{c}{ Variable } & $\begin{array}{c}\text { Regression } \\
\text { coefficient }\end{array}$ & $\begin{array}{c}\text { Standardized } \\
\text { Coefficient }\end{array}$ & t-value & \multicolumn{1}{c}{ Sig. t } \\
\hline Sharia financial Literacy & 0,100 & 0,163 & 0,610 & 0,543 \\
Attitude & 0,295 & 0,073 & 4,067 & 0,000 \\
Subjective norm & 0,015 & 0,106 & 0,146 & 0,884 \\
Behavioral control & 0,802 & 0,131 & 6,145 & 0,000 \\
Constant & & & & 0,474 \\
\hline R & & & & 0,907 \\
R Square & & & 0,822 \\
F & & & 123,426 \\
Sig F & & & 0,000 \\
\hline
\end{tabular}

Source: Primary Data (2019)

Based on the results, the regression equation of this research is:

$$
Y=0,474+0,100+0,295+0,015+0,802
$$

\section{a. Regression Coefficient Test (t Test)}

Based on the results of the test, the value of the Islamic financial literacy t-value of 0,610 with sig t $0,543(P>0,05)$, it can be interpreted that Sharia financial literacy has no significant effect on the intention of investing stocks in sharia stocks. Means $\mathrm{H} 1$ is rejected. Then the second hypothesis shows the t-value of the attitude variable of 4,067 with sig t $0,000(P<0,05)$, this means that the attitude variable is a significant effect on the intention of investing in sharia stocks. Means $\mathrm{H} 2$ is acceptable. The third hypothesis shows the t-value of 0,146 with a sig t of $0,884(p>0,05)$, thus the subjective norm variable has no significant Means $\mathrm{H} 3$ is rejected. Then the fourth hypothesis shows the t-value of 6,145 with sig t $0,000(P<0,05)$, thus the behavioral control variable has a significant relation to the intention of investing in sharia stocks. Means $\mathrm{H} 4$ received. 


\section{b. Simultaneous Testing (F test)}

Based on the test results, the F-value value is 123,426 with the sig $f 0,000(P<0,05)$ is thus collectively independent variables (sharia financial literacy, attitudes, subjective norms, dan behavioral control) have a positive relationship to the dependent variable (intention).

\section{c. Coefficient of Determination Test $\left(R^{2}\right)$}

Based on the results of the analysis, the value of $R^{2}$ is 0,822 which means that the contributions given by the variable are independent of the dependent variables of $82,2 \%$ while the remaining $17,8 \%$ are influenced by other factors outside of this study.

\section{Discussion}

\section{a. Influence of Sharia Financial Literacy on the Intention of Investing Sharia Stocks on Millennials}

Based on the results of multiple regression tests, sharia financial literacy against the intention of investing Sharia shares showed a t-value of 0,610 with sig t of 0,543 ( $p>0,05$ ). Thus, Sharia financial literacy has no significant relation to the intention of investing in sharia stocks. It is different from the first hypothesis. This is likely due to the behavior of millennials that are more concerned with hobbies, traveling, enjoying culinary experience than building assets early on.

\section{b. Influence of Attitudes on the Intention of Investing Sharia Stocks on Millennials}

Multiple regression test results indicate that the attitude variable has a t-value of 4.067 with a sig t of about $0.000(P<0.05)$, this means there is a positive and significant relationship to a variable attitude towards intent. It shows the second hypothesis acceptable. Based on the findings, when the more positive the person's attitude about the importance of investment, the higher the intention of individuals to make sharia investments, especially in sharia stocks.

\section{c. Influence of Subjective Norms on the Intention of Investing Sharia Stocks on Millennials}

Test results of subjective norms found a t-value of 0.146 with a value of sig t 0,884 ( $P>0,05)$, this means the subjective norms variable has no positive and significant relationship to the investment intention. It is different from the t third hypothesis. Based on this, social pressures both inside and outside have no influence to create the intention to invest in sharia stocks. This could be likely because they are not advised to jump directly into stock investments without learning first. Investments in stocks have the opportunity to gain substantial profits but have the risk of possible losses as well. 


\section{d. Influence of Behavioral Control on the Intention of Investing Sharia Stocks on Millennials}

IHTIFAZ - JIEFB

The results found that the behavior control variable had a $T$ value of 6.145 with a Sig $t$ value of $0.000(P<0.05)$, this means that the behavioral control variable has a positive and significant relationship to the intent of investing in sharia stocks. This corresponds to the fourth hypothesis. These findings supported the results gained from Maulana Saud, who found that behavioral control had an effect on internal Whistleblowing intentions. Based on this, the stronger the behavior control and accompanied by the ease of investing, the stronger the intention to invest especially in sharia stocks.

\section{CONCLUSION}

This research uses the Theory Planned Behavior (TPB) to know the intention of investing Sharia stocks on millennials, found the results of Sharia financial literacy and subjective norms do not affect the intention of investing. Attitude and behavioral control have a significant influence. As for simultaneous, all independent variables (Sharia financial literacy, attitudes, subjective norms, and behavioral control) affect the dependent variable (intention) to invest. The determinations test is 0.822 ; this means the contribution of independent variables of the dependent (intention) of about $82.2 \%$, while $17.8 \%$ influenced by other factors outside this study. As the Indonesian population is predominantly Muslim and with the number of millennials dominating about 88 million people (33\%), the Muslim millennials must understand the importance of investment. Sharia shares are one example of sharia investment that should be considered by Muslim millennials. In the present, there is no word too late to invest in sharia stocks. For further researchers, it is expected to use new variables and more data respondents to improve the quality and accuracy of the research.

\section{REFERENCES}

Adi, F., Sumarwan, U., \& Fahmi, I. (2018). Pengaruh Faktor Sikap, Norma Subjektif, Demografi, Sosioekonomi serta Literasi Keuangan Syariah dan Konvensional terhadap Minat Berwirausaha pada Mahasiswa. Al-Muzara'ah, 5(1), 1-20. https://doi.org/10.29244/jam.5.1.1-20

Ajzen, I. (1991). The theory of planned behavior. Organizational Behavior and Human Decision Processes, 50(2), 179-211. https:// doi.org/10.1016/0749-5978(91)90020-T

Ajzen, I. (2005). Attitudes, personality, and behavior. McGraw-Hill Education (UK).

Andika, M., \& Madjid, I. (2012). Analisis Pengaruh Sikap, Norma Subyektif dan Efikasi Diri Terhadap Intensi Berwirausaha pada Mahasiswa. Eco Entrepreneurship Seminar \& Call for Paper "Improving Performance 
by Improving Environment,"190-197. https://doi.org/10.1007/9781-4419-0143-0

Arwani, A. (2015). Pengaruh Sikap Mahasiswa Muslim Terhadap Minat pada Bank Syariah. Jurnal Penelitian, 12(1), 1. https://doi. org/10.28918/jupe.v12i1.640

Chen, H. (1998). An analysis of personal financial literacy among college students. Financial Services Review, 7(2), 107-128. https://doi. org/10.1016/S1057-0810(99)80006-7

Darmawan, A., Kurnia, K., \& Rejeki, S. (2019). Pengetahuan Investasi, Motivasi Investasi, Literasi Keuangan dan Lingkungan Keluarga Pengaruhnya terhadap Minat Investasi di Pasar Modal. Jurnal Ilmiah Akuntansi Dan Keuangan, 8(2), 44-56. https://doi.org/10.32639/ jiak.v8i2.297

Denan, Z., Othman, A. A., Noor, M., Ishak, I., Fazril, M., Kamal, M., \& Hasan, M. H. (2015). The Theory of Planned Behavior and SelfIdentity Factors Drive Graduates to Be Indebtedness. 5(4). https:// doi.org/10.7763/IJSSH.2015.V5.477

Faidah, F. (2019). Pengaruh Literasi Keuangan Dan Faktor Demografi Terhadap Minat Investasi Mahasiswa. JABE (Journal of Applied Business and Economic), 5(3), 251. https://doi.org/10.30998/jabe. v5i3.3484

Fishbein, M., \& Ajzen, I. (1977). Belief, attitude, intention, and behavior: An introduction to theory and research. Addison-Wesley.

HC, R. H. K., \& Gusaptono, R. H. (2020). The Impact of Financial Literacy on Investment Decisions Between Saving and Credit: Studies on Sharia Bank Customers in the Special Region of Yogyakarta. Journal of Economics and Business, 3(4). https://doi.org/10.31014/ aior.1992.03.04.291

Huston, S. J. (2010). Measuring Financial Literacy. Journal of Consumer Affairs, 44(2), 296-316. https://doi.org/10.1111/j.17456606.2010.01170.x

Lusardi, A. (2019). Financial literacy and the need for financial education: evidence and implications. Swiss Journal of Economics and Statistics, 155(1), 1. https://doi.org/10.1186/s41937-019-0027-5

Mandell, L. (2008). Financial Literacy of High School Students. In Handbook of Consumer Finance Research (pp. 163-183). Springer New York. https://doi.org/10.1007/978-0-387-75734-6_10

Maulana Saud, I. (2016). Pengaruh Sikap dan Persepsi Kontrol Perilaku Terhadap Niat Whistleblowing Internal-Eksternal dengan Persepsi Dukungan Organisasi Sebagai Variabel Pemoderasi. Jurnal Akuntansi Dan Investasi, 17(2), 209-219. https://doi.org/10.18196/ jai.2016.0056.209-219 
Muhamad. (2016). Manajemen Keuangan Syariah Analisis Fiqh \& Keuangan (Kedua). UPP STIM YKPN.

IHTIFAZ - JIEFB

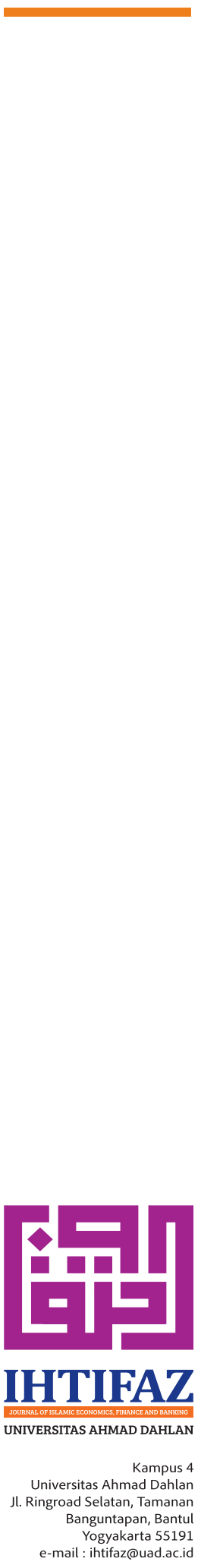

Nugroho, A.P., Hidayat, A., \& Kusuma, H. (2017). The influence of religiosity and self-efficacy on the saving behavior of the slamic banks. Banks and Bank Systems, 12(3). https://doi.org/10.21511/ bbs.12(3).2017.03

Nugroho, Anton Priyo. (2015). Pengaruh Religiusitas dan Efikasi Diri Terhadap Perilaku Menabung di Perbankan Syariah. Disertasi Doktor.

Nugroho, Anton Priyo, Izzat, D., \& Suhasti, W. (2019). Peran Identitas Agama Terhadap Niat Menggunakan Kosmetik Halal : Perluasan Theory of Planned Behavior. Ihtifaz: Journal of Islamic Economics, Finance, and Banking, 2(2), 89. https://doi.org/10.12928/ijiefb. v2i2.921

Paul, J., Modi, A., \& Patel, J. (2016). Journal of Retailing and Consumer Services Predicting green product consumption using theory of planned behavior and reasoned action. Journal of Retailing and Consumer Services, 29, 123-134. https://doi.org/10.1016/j. jretconser.2015.11.006

Ruslim, T. S., Rahardjo, M., \& Widjaya, H. (2017). Pengaruh Subjective Norm dan Perceived Behavioral Control terhadap Intention to Commit Digital Piracy. Jurnal Ekonomi, 22(3). https://doi. org/10.24912/je.v22i3.283

Salsabila, B. R., \& Nurdin. (2019). Pengaruh Literasi Keuangan Terhadap Keputusan Investasi Investor di Galeri Investasi BEI Maranatha Effects of Financial Literacy on Investors' Investment Decisions in the Maranatha IDX Investment Gallery. 5(1), 219-226. https://doi. org/http://dx.doi.org/10.29313/.v0i0.15123

Shofwa, Y. (2017). Pengaruh Motivasi dan Literasi Keuangan Terhadap Minat Berinvestasi Di Pasar Modal. Jurnal Penelitian Agama, 18(2), 290-301. https://doi.org/10.24090/jpa.v18i2.2017.pp290-301

Sujarweni, V. W. (2008). Belajar Mudah SPSS untuk Penelitian. Yogyakarta: Global Media Informasi.

Sulistianingtyas, V., Rosidi, R., \& Subekti, I. (2018). A Perspective of Theory of Planned Behavior and Attribution Theory for PBB P2 Taxpayer Compliance in Probolinggo. Journal of Accounting and Business Education, 2(2), 320-347. https://doi.org/10.26675/jabe. v2i2.11232

van Gelderen, M., Brand, M., van Praag, M., Bodewes, W., Poutsma, E., \& van Gils, A. (2008). Explaining entrepreneurial intentions by means of the theory of planned behaviour. Career Development International, 13(6), 538-559. https://doi.org/10.1108/13620430810901688 